\title{
Poisonous Plants and Plant Toxins That Are Likely to Contaminate Hay and Other Prepared Feeds in the Western United States
}

\author{
By B. L. Stegelmeier and K. E. Panter
}

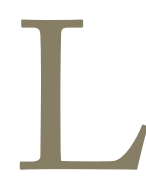

ivestock poisoning by toxic plants is a relatively common problem in pastures and rangelands and it is estimated to annually cost the livestock industry more than $\$ 200$ million. ${ }^{1}$ However, these estimates are for grazing animals and the total cost is probably much greater because many animals are poisoned by contaminated feeds. Many poisonous plants are accessible to grazing livestock, but they are generally avoided and are not eaten, or they are eaten at doses that they do not produce detectable disease. In such cases toxic plants may not be more than a problem of displacing desirable nutritious plants. However, this is not always the case, especially when toxic plants contaminate prepared feeds. Poisonous plants incorporated in preserved forages, such as hay and silage, are much more likely to be eaten. This may occur because of increased competition from herd mates or by increased feeding pressure as prepared feeds are most often used in winter when alternative food sources are exhausted. Alternatively, the plants may become more palatable as they are diluted with palatable feed or the previously distasteful plant components are altered during forage preparation or storage. In addition, normally safe forages, under certain conditions, can produce and accumulate toxins. Identifying these toxic contaminates and understanding when forages may be toxic is critical in reducing poisoning and ensuring quality animal products. Our objectives of this review are to present basic principles of identifying contaminated feeds and sampling forages, introduce several common forages that under certain conditions can be toxic, present a brief description of plants that we have found contaminating feed in the western United States, and review how to treat or avoid such poisonings.

\section{Sampling Contaminated Feeds to Identify Poisonous Plants and Their Toxins}

Plant toxin contamination of feeds and foods most commonly occurs when poisonous plants invade pastures and fields and are harvested along with the desired forage or grain. Such invasions are not uniform, so contamination is often not evenly distributed. This presents a challenge to those attempting to identify toxic plants within the forage. Forage harvesting often damages and removes many of the characteristic parts of individual plants, making finding and identifying plants within a load of hay or silage difficult. Since contamination is usually nonuniform, appropriate sampling technique is critical. Many times only four or five bales of hay from a field of several hundred may contain enough contamination to cause disease. Consequently, numerous representative samples should be examined to provide the best chance of finding evidence of contamination. Livestock producers and animal caretakers may be the most appropriate inspectors because they can examine feed when it is fed and collect suspicious or unidentified plants. Certainly the best way to be aware of potential contamination is to inspect the field before it is harvested. Local extension agents and veterinarians are often familiar with local plants and animal diseases and they are excellent resources to help with these problems.

Identifying toxic plants can be challenging. Unknown plants may be collected and sent to a local laboratory, plant taxonomist, or herbarium. These are found in association with universities, museums, and botanical gardens. Positive identification is more likely if an entire plant is submitted. Flowers and seed pods are often essential for making a definitive identification. If a local herbarium is not available, the sample should be dried and pressed by placing it between newspapers pressed down under a couple of large books for 2 to 3 days. The plant can then be taped to a piece of cardboard, or placed in a folder, and mailed to the appropriate laboratory (see Table 1). A fresh, undried sample sent in a plastic bag can arrive at a laboratory looking more like green soup than a plant, so it is worthwhile to take the time to prepare a sample. 
Table 1. List of potential references and resources

\begin{tabular}{l|l|l|}
\hline Resource & Phone number & \multicolumn{1}{c}{ Web site } \\
\hline $\begin{array}{l}\text { Local extension agent } \\
\text { USDA/Agricultural Research Service } \\
\text { Poisonous Plant Research Laboratory }\end{array}$ & $1-435-752-2941$ & http://www.csrees.usda.gov/Extension \\
\hline $\begin{array}{l}\text { State animal disease diagnostic laboratory } \\
\text { hocal herbarium }\end{array}$ & & $\begin{array}{l}\text { http://www.aavld.org/mc/page.do?sitePageld=33930\&orgl } \\
\text { d=aavld (laboratories accredited by American Association } \\
\text { of Veterinary Diagnostic Laboratories) }\end{array}$ \\
\hline $\begin{array}{l}\text { Texas Veterinary Medical Diagnostic } \\
\text { Laboratories-microscopic analysis of feces } \\
\text { and ingesta to detect toxic plant parts }\end{array}$ & $1-888-646-5623$ & $\begin{array}{l}\text { httherba.msu.ru/mirrors/www.helsinki.fi/kmus/botmus. } \\
\text { html (list of public herbaria throughout the world) }\end{array}$ \\
\hline
\end{tabular}

Not all plants, even within the same species, contain toxins and the toxin concentrations may vary. Some plants might need to be analyzed chemically to confirm they present a risk. Such plants can be collected green and frozen, if they can be maintained frozen until analysis. Many plant toxins are heat- and drying-stable and they can be dried before shipment. Laboratories are likely to require specific information about the collection and it is best to check with them to ensure that the submission is complete and the laboratory will be ready to receive the package.

Some toxins can be found relatively homogenously throughout the feed. For example, prepared feeds, such as hay pellets, are extensively processed, which homogenizes the sample. Because the processing precludes visual inspection for contamination, such forages need to be analyzed chemically to detect contamination. Again it is essential that several representative samples of the feed be collected (see Table 2).

\section{Diagnosing Disease in Livestock Fed Contaminated Feed}

If animals are poisoned, to identify the actual cause it is necessary to collect samples for analysis and histological examination, as well as for clinical studies and postmortem examination. Because many nutritional, genetic, and infectious diseases can cause clinical diseases and lesions similar to those produced by toxic plants, involvement of local veterinarians and state diagnostic laboratories is key (see Tables 1 and 2). The proper examination and collection of samples often result in a definitive diagnosis. For example, the eye of a dead animal can be analyzed chemically, and if the nitrate concentrations are elevated, it is diagnostic for plant-associated nitrate poisoning (dark, almost chocolatecolored blood taken from dying animals also indicates nitrate/nitrite poisoning). At times the examinations and results produce no definite diagnosis, but are still useful as they can be used by a diagnostic center to generate a list of potential causes. With further investigation this list can be shortened to identify the most likely cause. Then appropriate action can be taken to avoid future problems or minimize the impact of that particular toxic plant.

\section{Specific Plant Toxins That May Contaminate Feeds and Poisoning Syndromes}

Below we list some of the most common toxins and poisonous plants that we have found to contaminate feeds and that are likely to cause problems in the western United States. The list is not complete and readers may want to consult more inclusive books and Web pages for additional information. ${ }^{2,3}$ We also review how to treat or avoid poisonings by each plant toxin.

\section{Bloat-Inducing Agents}

Bloat is a common name for increased rumen pressure or tympany and it probably is the most common plantassociated toxicity related to prepared feeds. Bloat has various causes, but the type associated with lush green forages is commonly called frothy bloat. Common plants that are commonly associated with bloat include alfalfa (Medicago sativa), ladino clover (Trifolium repens), red and white clover (Trifolium spp.), green cereal crops, rape and kale (Brassica spp.), and others that contain soluble and quickly digested proteins, saponins, and hemicelluloses. These compounds are suspected to alter rumen surface tension and stabilize surface foam. ${ }^{4}$ Tannin-containing legumes, such as sainfoin (Onobrychis spp.), crown vetch (Securigera spp.), milk vetch (Astragalus spp.), fenugreek (Trigonella spp.), and birdsfoot trefoil (Lotus corniculatus), have similar proteins, but they are more slowly digested and rarely cause bloat. ${ }^{5}$ Recently much work has been done to develop bloat-resistant cultivars of desirable species to minimize the incidence and severity of this disease. Bloat is most often seen when animals are allowed to graze rapidly growing lush pastures, but it can also been seen when animals are fed 


\begin{tabular}{|c|c|c|c|}
\hline Test & Sample & Size & Shipping \\
\hline Blood counts & $\begin{array}{l}\text { EDTA-containing blood tube } \\
\text { (often a purple-topped tube) }\end{array}$ & $3-5 \mathrm{~mL}$ & Chilled shipped on ice \\
\hline Serum biochemistries & $\begin{array}{l}\text { Clot tube (often a red-topped } \\
\text { tube), contains no anticoagulant. } \\
\text { The serum is separated from the } \\
\text { cellular portions after clotting. }\end{array}$ & $5-10 \mathrm{~mL}$ & $\begin{array}{l}\text { Chilled on ice or frozen for } \\
\text { extended delivery }\end{array}$ \\
\hline $\begin{array}{l}\text { Microscopic evaluation of } \\
\text { tissues }\end{array}$ & $\begin{array}{l}\text { Various tissues (liver, heart, lung, } \\
\text { kidney, gastrointestinal tract, } \\
\text { brain, and any lesions) }\end{array}$ & $2 \times 2 \times 4 \mathrm{~cm}$ pieces & Fixed in formalin \\
\hline Postmortem or necropsy & Dead or moribund animal & Whole animal & Fresh \\
\hline $\begin{array}{l}\text { Chemical evaluation of } \\
\text { serum, blood, eye fluid, } \\
\text { urine, or milk }\end{array}$ & $\begin{array}{l}\text { Serum, whole blood, urine, or } \\
\text { milk. The whole eye is the best } \\
\text { sample to send if nitrate } \\
\text { poisoning is suspected. }\end{array}$ & $20 \mathrm{~mL}$ & $\begin{array}{l}\text { Stored in tubes or plastic } \\
\text { bags and shipped on ice or } \\
\text { frozen }\end{array}$ \\
\hline $\begin{array}{l}\text { Chemical evaluation of } \\
\text { tissue }\end{array}$ & Various tissues & $2 \times 2 \times 4 \mathrm{~cm}$ pieces & $\begin{array}{l}\text { Stored in plastic bags and } \\
\text { shipped frozen }\end{array}$ \\
\hline $\begin{array}{l}\text { Chemical evaluation of } \\
\text { feces or gastrointestinal } \\
\text { contents }\end{array}$ & Feces or ingesta & $\begin{array}{l}1 \mathrm{~kg} \text { (about a sandwich } \\
\text { bag full) }\end{array}$ & $\begin{array}{l}\text { Stored in plastic bags and } \\
\text { shipped frozen }\end{array}$ \\
\hline Plant identification & Whole plant & $\begin{array}{l}\text { Whole plant including } \\
\text { flowers, pods, leaves, } \\
\text { stems and roots }\end{array}$ & $\begin{array}{l}\text { Fresh if delivered that day, } \\
\text { dried if hand delivered later, } \\
\text { pressed and dried if sent } \\
\text { through the mail }\end{array}$ \\
\hline Plant chemical analysis & Whole plants & 5 or 6 whole plants & $\begin{array}{l}\text { Fresh if delivered that day, } \\
\text { dried if mailed or frozen if } \\
\text { they can be maintained } \\
\text { frozen during shipping }\end{array}$ \\
\hline $\begin{array}{l}\text { Weed contamination of hay } \\
\text { and weed identification }\end{array}$ & Stored baled hay & 5 or 6 bales & Dry \\
\hline Nitrate analysis in hay & Hay & $\begin{array}{l}\text { Several representative } \\
\text { samples. These can be } \\
\text { core samples. } 0.5-1 \mathrm{~kg}\end{array}$ & Dry \\
\hline Prepared feeds & Feeds & $\begin{array}{l}\text { Representative feed } \\
\text { samples such as cubed } \\
\text { feed. } 0.5-1 \mathrm{~kg}\end{array}$ & Dry \\
\hline $\begin{array}{l}\text { Silage or green chopped } \\
\text { feed }\end{array}$ & Feeds & $\begin{array}{l}\text { Representative feed } \\
\text { samples. } 3-5 \mathrm{~kg}\end{array}$ & Frozen \\
\hline
\end{tabular}

high-quality hay. Frothy bloat can also be seen in animals fed grain diets. The causes of these grain-related cases are probably related to rapid fermentation, acidosis, and microbial production of foam-stabilizing compounds. ${ }^{6}$

Clinically, bloat is seen as marked distension of the abdomen with prominent rumen distension seen in the left paralumbar fossa. This distension and pressure results in dyspnea (labored breathing) seen as grunting and open-mouthed breathing, accompanied by extension of the neck and regurgitation of rumen contents. If untreated, most animals affected in this way quickly die. Death may occur within an hour of exposure, but most cases develop within 3 to 4 hours of exposure. Emergency treatment is to relieve the pressure via a trocar, cannula, or rumenotomy. In less 
Table 3. Partial list of plants predisposed to accumulate toxic nitrate concentrations $(>0.5 \%)$ that may contaminate hay and prepared forages ${ }^{8}$

\begin{tabular}{|l|l|}
\hline Common name & \multicolumn{1}{|c|}{ Scientific name } \\
\hline Sudan grass & Sorghum bicolor \\
\hline Johnsongrass & Sorghum halepense \\
\hline Sorghum & Sorghum spp. \\
\hline Fireweed & Kochia scoparia (Fig. 2) \\
\hline Beets & Beta spp. \\
\hline Rape & Brassica spp. \\
\hline Corn & Zea spp. \\
\hline Rye & Secale cereale \\
\hline Wheat & Triticum spp. \\
\hline Oats & Arena sativa \\
\hline Fescue & Festuca spp. \\
\hline Alfalfa & Medicago sativa \\
\hline Sweet clover & Melilotus officinalis \\
\hline Flax and linseed & Linum spp. \\
\hline Lambsquarter & Chenospdium album \\
\hline Canadian thistle & Cirsium arvense \\
\hline Jimsonweed & Datura stramonium \\
\hline Wild sunflower & Helianthus spp. \\
\hline Cheeseweed & Malva parviflora \\
\hline Smartweed & Polygonum spp. \\
\hline Dock & Rumex cripus \\
\hline Nightshades & Solanum spp. \\
\hline Soybean & Glycine max \\
\hline Pigweed & Amaranthus spp. \\
\hline
\end{tabular}

severe cases rumen pressure can be relieved using a stomach tube. Antifoaming agents such as vegetable and mineral oils with various surfactants such as poloxalene are commonly used. Preventing bloat is difficult and most strategies only reduce the incidence. Supplemental feeding, mixed seeding, and strip grazing can be used to limit the doses of quickly growing legumes to less than $30 \%$ of the diet; antifoaming agents mixed with minerals can be used to reduce the risk; and timed release rumen capsules containing ionophores are also helpful. ${ }^{4}$

\section{Nitrate/Nitrite Poisoning}

Another relatively common toxicity occurs when certain pasture and cultivated forages accumulate toxic concentrations of nitrates. In ruminants, nitrates are quickly reduced to

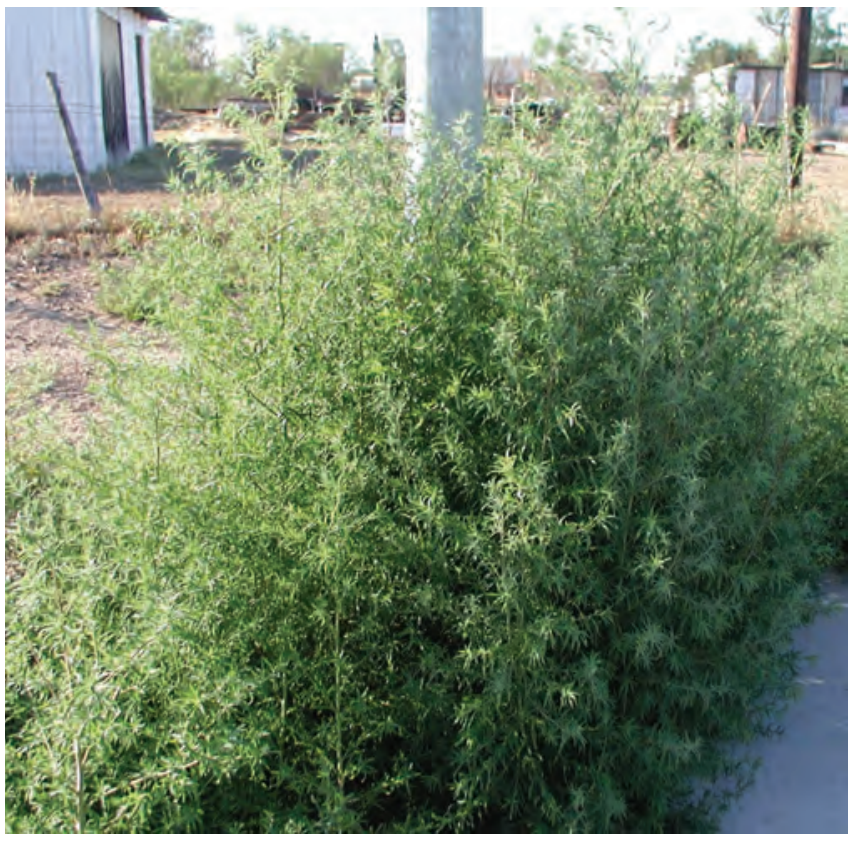

Figure 1. Kochia (Kochia scoparia) is an annual weed originally introduced from Asia. It is a rapidly growing, branching plant, with alternate hairy leaves. It can grow up to $2 \mathrm{~m}$ tall and it is commonly found in disturbed areas of fields, pastures, and rangelands. In some parts of the world it is used as forage, but in North America it has been associated with liver disease, photosensitivity, polioencephalomalacia, and nitrate poisoning. Other than nitrate poisoning, the toxin or mechanism of toxicity has never been proven for kochia.

nitrite which is absorbed and oxidizes hemoglobin, producing methemoglobin. Methemoglobin will not bind oxygen and is therefore nonfunctional. In monogastric animals such as horses the nitrates are not so easily reduced and doses of nearly $120 \mathrm{~g}$ are required to be toxic. ${ }^{7}$ Signs of nitrite poisoning include weakness, trembling, brown or cyanotic mucous membranes, dyspnea, brown discolored blood, abortion, and death. Poisoning is cumulative and all other potential sources, such as water or feed additives, should be considered. Nitrates accumulate in all plant parts but may be especially high in stalks and leaves. Seeds or grains are generally safe. Plants predisposed to accumulate toxic nitrate concentrations $(>0.5 \%)$ are listed in Table 3, which includes many weeds that commonly invade forages. ${ }^{8}$ For example, kochia (Kochia scoparia; Fig. 1) accumulates nitrates and often contaminates recently planted hay fields. Nitrate accumulation is provoked by nitrogen fertilization, drought or frost stress, and some herbicide treatments. Water may be contaminated with nitrates from fertilizer, silage-pit, or feedlot runoff.

Poisoned animals may be treated with intravenous methylene blue $(8 \mathrm{mg} / \mathrm{kg}$ in cattle). Because methylene blue is rapidly cleared, treatment may need to be repeated every 2 hours. In most cases the animals die quickly, precluding treatment. The diagnosis postmortem is best made analyzing the eye for nitrates. The whole globe should be submitted 
Table 4. Partial list of pyrrolizidine alkaloidcontaining plants that have poisoned livestock and may contaminate hay and prepared forages ${ }^{12}$

\begin{tabular}{|l|l|}
\hline Scientific name & Common name \\
\hline $\begin{array}{l}\text { Senecio douglasii var. } \\
\text { longilobus }\end{array}$ & Woody groundsel \\
\hline Senecio glabellus & Butterweed \\
\hline Senecio intergerrium & Lamb's tongue groundsel \\
\hline Senecio jacobaea & Tansy ragwort \\
\hline Senecio plattensis & Prairie ragwort \\
\hline Senecio riddellii & Ridell's ragwort \\
\hline Senecio spartioides & Broom groundsel \\
\hline Senecio vulgaris & Common groundsel \\
\hline Crotalaria retusa & Wedge leaf rattlebox \\
\hline Crotalaria sagittalis & Rattlebox \\
\hline Crotalaria spectabilis & Showy crotalaria or rattlebox \\
\hline Amsinckia intermedia & Fiddleneck, tarweed \\
\hline Cynoglossum officinale & Hound's tongue \\
\hline Echium vulgare & Blue weed, Viper's bugloss \\
\hline Symphytum officinale & Comfrey \\
\hline
\end{tabular}

as the nitrates in this tissue are slow to be altered by autolysis and saprophytic bacteria (see Table 2).

Nitrate poisoning can be prevented by recognizing crops, weeds, and forages that are likely to accumulate nitrates and avoiding contact with susceptible species. Forage nitrate concentration of $>0.5 \%$ and water concentrations $>200 \mathrm{ppm}$ should be considered dangerous. Contaminated forages can still be used if they are diluted with good feed or fed to less-susceptible species.

\section{Pyrrolizidine Alkaloid-Containing Plants}

This group of plants is large and distributed worldwide, where it includes over 6,000 species that may contain over 650 different toxins. In the United States the list is shorter, but Pyrrolizidine Alkaloid (PA)-containing plants can be found in every state. As a group they are not very palatable, but when they are included in hay or other prepared forages, they are readily accepted and eaten. The PA toxins primarily damage the liver, resulting in nonspecific but suggestive histological changes (liver necrosis, fibrosis, biliary hyperplasia, and megalocytosis). These lesions are dependent on the dose and duration of poisoning. High doses produce extensive damage or necrosis of the liver. This is seen clinically as acute liver failure with jaundice (icterus), coagulopathy, and hepatic encephalopathy. Lower doses are more common and also damage the liver. However, in these cases the liver damage is less severe, but often results in compromised animals with reduced hepatic function. Such animals may decompensate and develop clinical liver disease months and even years after the initial exposure. Clinical disease in these animals includes icterus, photosensitivity, weight loss, and poor production. Such liver failure is often precipitated by a stressful event such as pregnancy, lactation, poor nutrition, or bad weather. This delayed onset of disease complicates diagnosis because the causative contaminated feed is gone and cannot be examined.

Most PA-containing plants are invasive noxious weeds of varying toxicity, making it difficult to predict the risk and the extent or effect of poisoning. Animal and individual susceptibility to poisoning also differs. Horses and cattle are more susceptible than sheep and goats, and rabbits are particularly resistant to PA. Young animals are often much more susceptible than mature animals and there are reports of newborns being poisoned through their mother's milk without the mother experiencing clinical toxicity. ${ }^{9}$ Selected PA-containing plants (Table 4) include hound's tongue (Cynoglossum officinale; Fig. 2) and several different

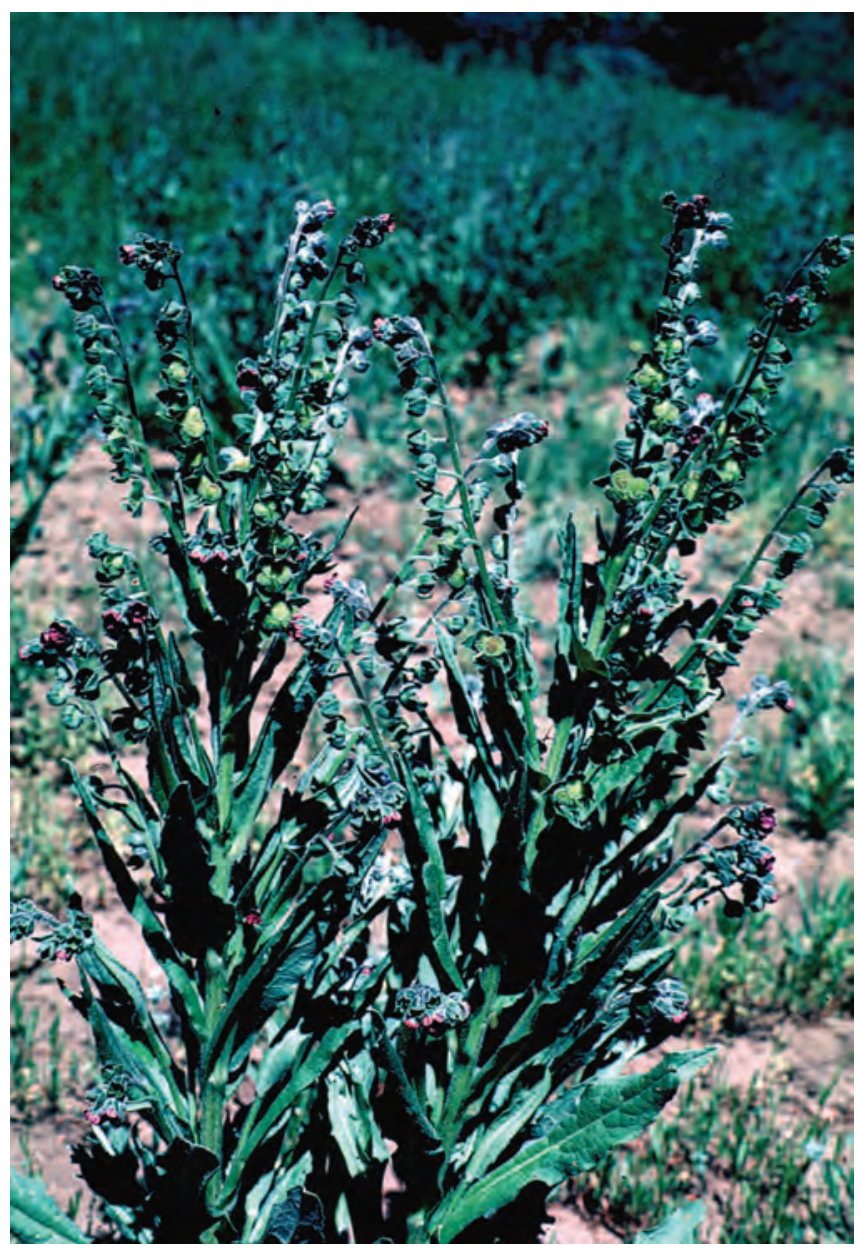

Figure 2. Hound's tongue (Cynoglossum officinale) is a biennial noxious weed originally from Euroasia that has spread throughout North America. The leaves of the first-year rosette are long $(40+\mathrm{cm})$ and broad, hence the common name. In its second year the plant produces flowering stems that are about $0.5 \mathrm{~m}$ tall and topped with reddish-purple flowers that ripen into small 8-10-mm nutlets that are coverd with hooked barbs that easily attach to hair and clothing. 


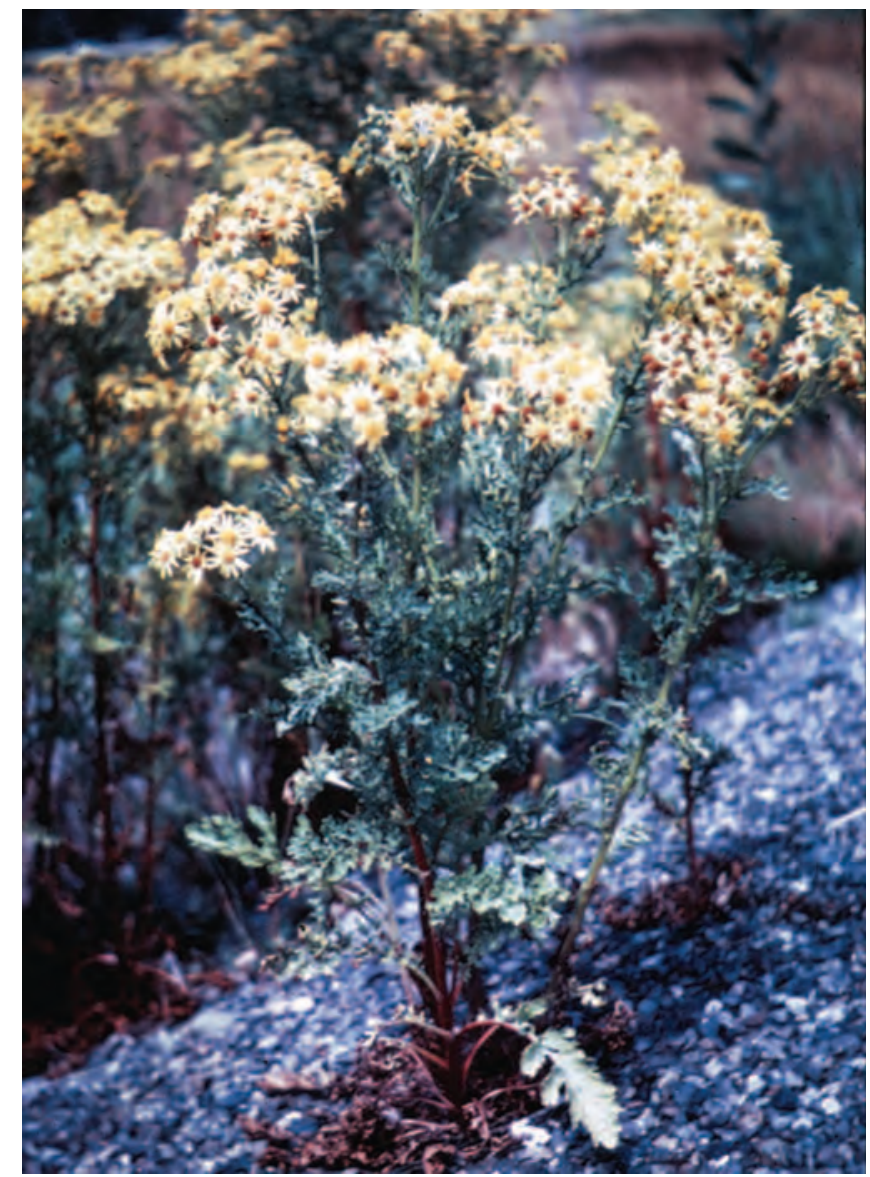

Figure 3. Tansy ragwort (Senecio jacobaea) is a noxious weed that is a native of the British Isles that has spread into Western Europe, South Africa, Australia, New Zealand, and North America. It commonly invades fields and pastures in the Pacific Northwest. In spite of extensive control efforts using chemical and biologic agents, it continues to be a problem. Tansy ragwort is a tall $(0.5-1.5 \mathrm{~m})$, erect plant that is unbranched except at the inflorescence. Poisoning occurs when plants contaminate feeds, when grazing animals cannot easily differentiate the early rosette from grasses and clovers, or when no other forages are available. Tansy ragwort contains six major alkaloids, of which several have been shown to cross the placenta and to be secreted in milk.

Senecio species (see tansy ragwort, Senecio jacobea; Fig. 3). PA-containing plants are the most likely to contaminate grain and herbal products. Consequently human poisonings and deaths have been reported. ${ }^{10}$ Comfrey root and foliage also contains significant concentrations of $\mathrm{PA}$, which is why wise herbalists no longer make tea of it and use it as an externally applied medication only. PA-containing plants remain toxic in prepared feeds and food with minimal degradation in most ensiling processes. ${ }^{11}$ Cereal products can be contaminated by dust alone when they are coharvested with PA-containing plants. PAs have also been identified in honey, milk, and animal tissues. ${ }^{12}$

Because most animals that develop clinical disease die, treatment of PA-poisoned animals is limited. Though little is known about subclinically poisoned animals, it is speculated that they have permanent loss of hepatic function and are not likely to perform to their full potential. Consequently,

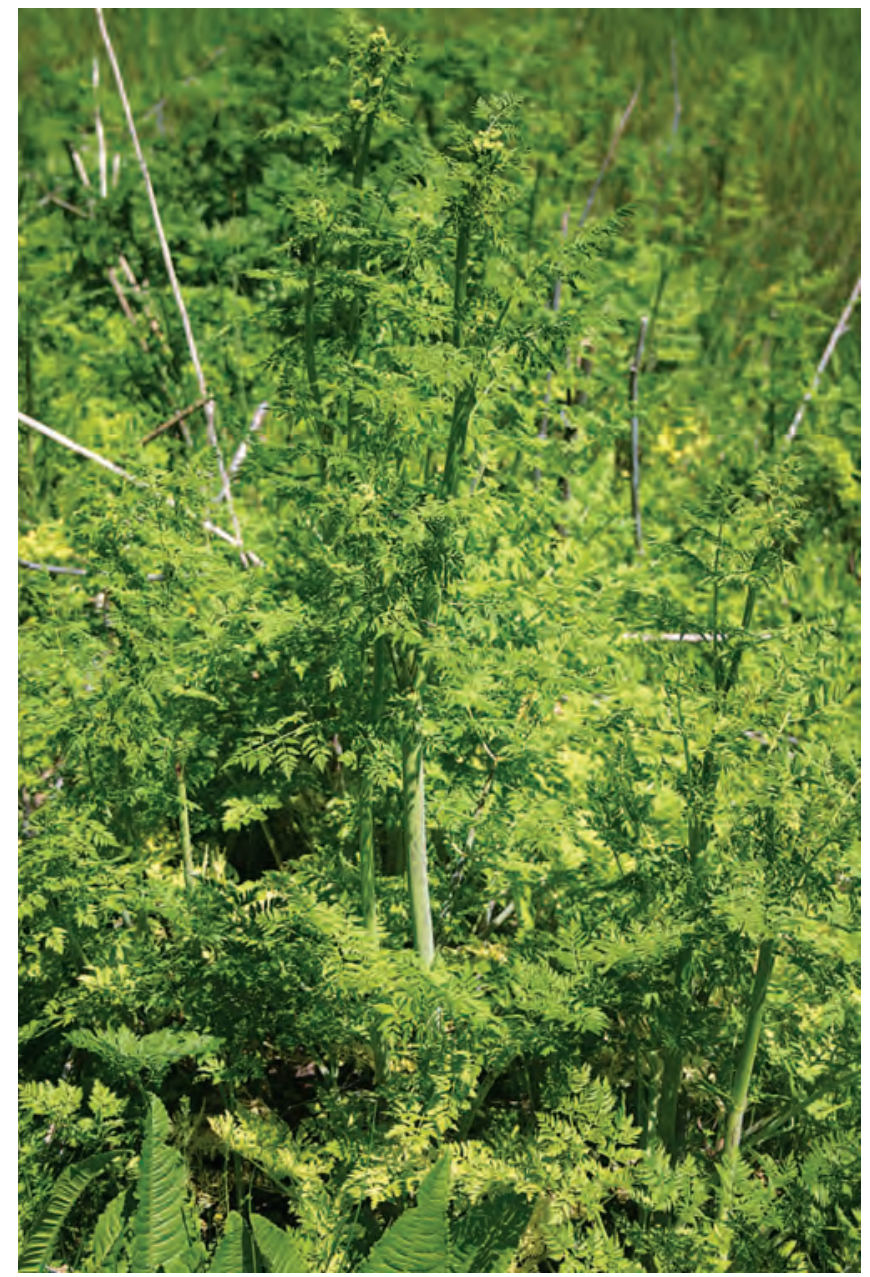

Figure 4. Poison hemlock (Conium maculatum) is an erect biennial that grows up to $2 \mathrm{~m}$ tall. Originally from Europe, it now grows throughout North America and it is commonly found along ditches and roads where the ground is moist. The stems are smooth and hollow and they often have purple spots. The leaves are carrot-like, alternate, pinnately dissected, and coarsely toothed. The inflorescence is a flat-topped umbel with multiple small white flowers.

avoiding exposure is the suggested treatment. As with many other toxic plants, the best way to ensure feed quality is to inspect the fields for invasion by these plants prior to harvest.

\section{Poison Hemlock (Conium maculatum)}

Poison hemlock (Fig. 4) is an introduced biennial or perennial plant that grows along roads, ditches, and fences. It commonly invades into adjacent fields and pastures. Animals most often avoid eating poison hemlock unless there are no other forages available. The toxins (conine and gamma-coniceine) affect poisoned animals similarly to nicotine, causing muscle tremors, salivation, incoordination, dyspnea, increased defecation and urination, and death. If not acutely fatal, abortions and birth defects also occur.

The leaves and stems are toxic and may contaminate hay and silage. The seeds are highly toxic and can contaminate cereal grains. Fortunately, these toxins are not as stable as many other plant toxins and they degrade over several months in 


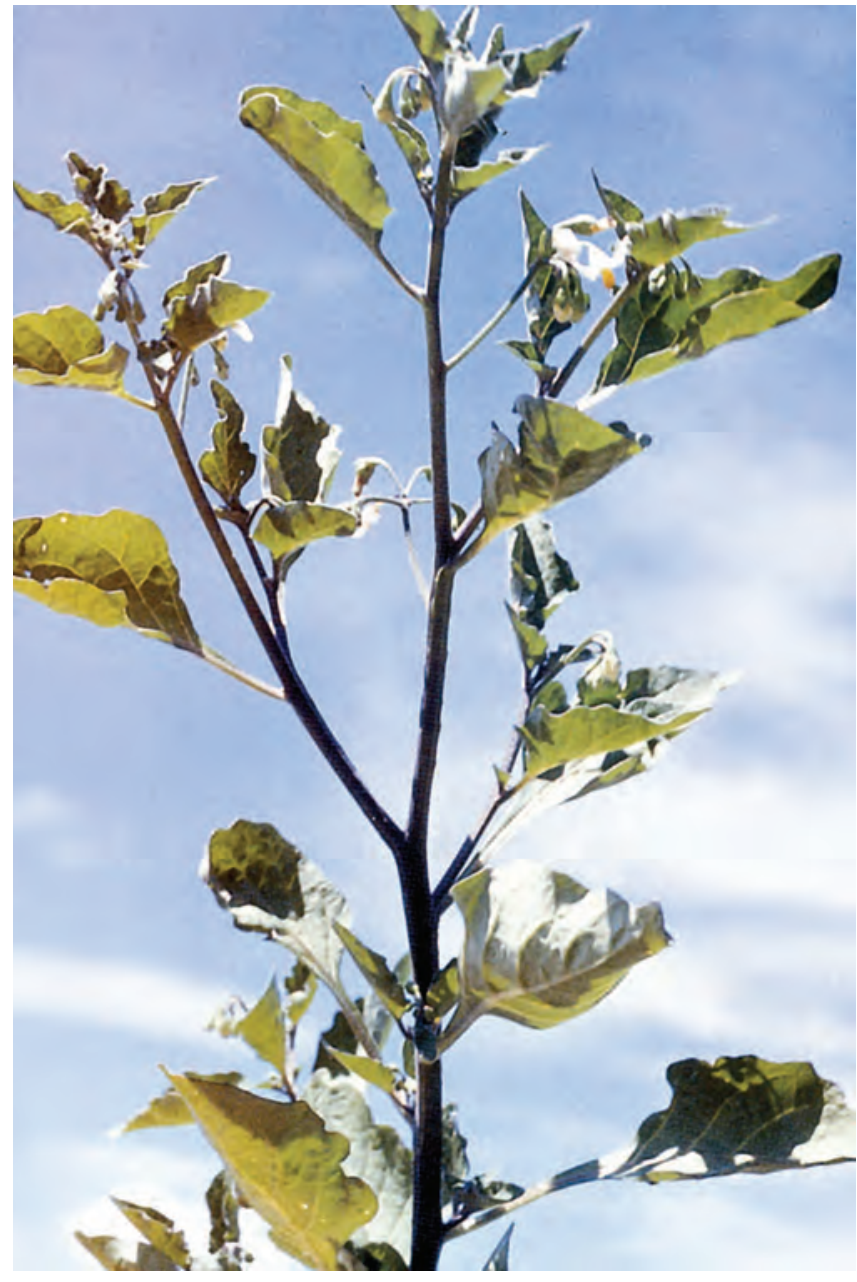

Figure 5. Black nightshade (Solanum nigrum) is a spineless erect or trailing annual plant that grows along fences and roads and on the disturbed margins of fields. It has a small white flower that ripens into a 0.5-1-cm round, smooth, green fruit that contains the toxin, solanine. When the fruits turn black, they are edible and not toxic.

most hay and prepared feeds. However, this degradation may not be uniform, resulting in some portions of the prepared feed having residual toxicity. Nearly always, the fresh plant material is uniformly toxic and most poisonings occur when animals are fed contaminated fresh, chopped forages. ${ }^{13}$

There are no specific treatments for poison hemlock poisoning and most animals recover if they are removed from the source of the toxins and allowed to recover with minimal stress. Supportive care might include a cathartic or administration of activated charcoal to minimize absorption.

\section{Black Nightshade (Solanum nigrum), Jimsonweed (Datura stramonium), and Henbane (Hyoscyamus niger)}

Black nightshade (Fig. 5) is found along fences and roads throughout North America. It contains several glycoalkaloids, including solanine, hyoscine, and hyoscamine. These toxins are similar to atropine and alter the function of the autonomic nervous system. Consequently they alter salivation

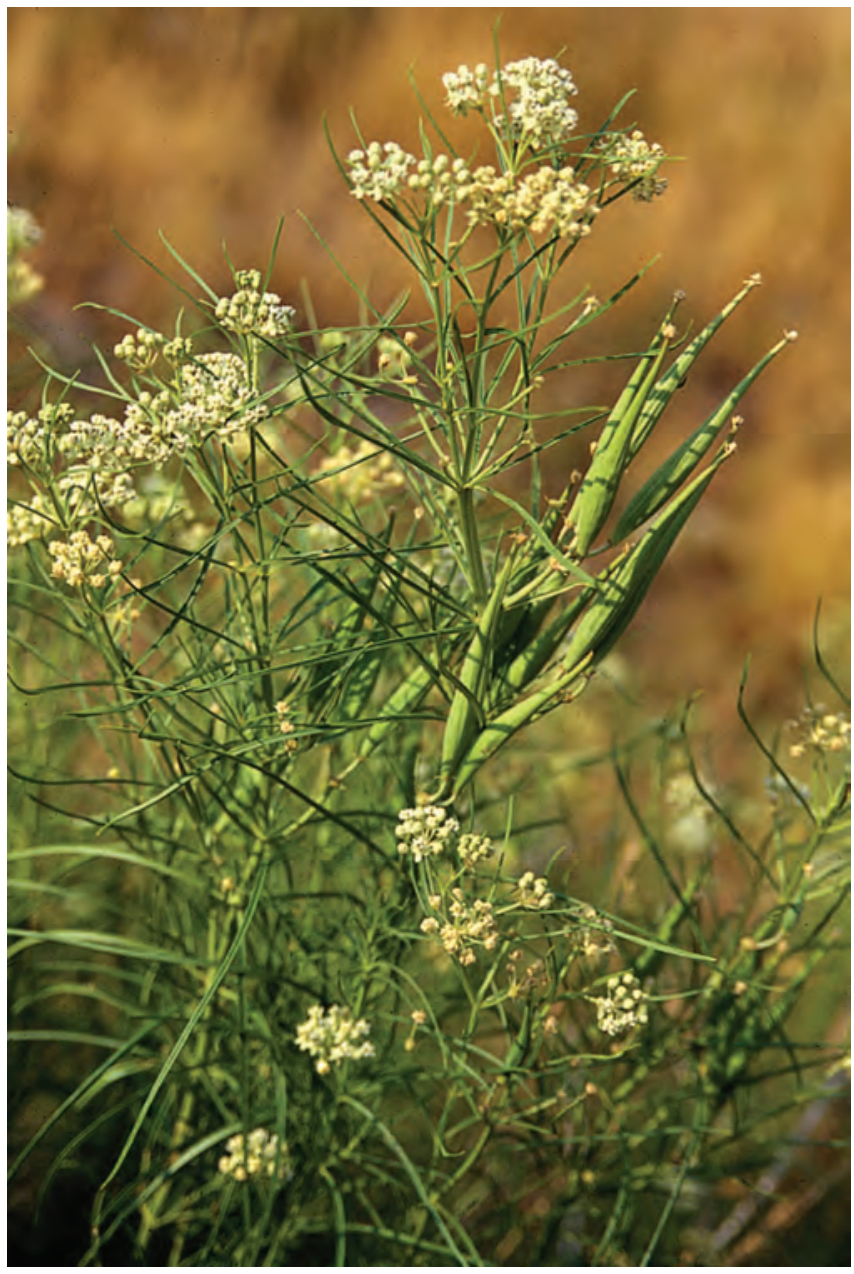

Figure 6. Milkweed (Asclepias subverticillata) is pictured above. Milkweeds (Asclepias spp.) are found throughout the world along road, waterways, and in disturbed areas on the margins of fields and pastures. They are erect perennials that generally have broad veined leaves. Most contain milky sap or latex and the flowers are usually terminal umbels colored from greenish white to red.

and decrease gastrointestinal motility. Under some conditions this can result in epidemic incidences of colic. Similar problems have been documented to occur when grains contaminated with jimsonweed seeds were fed to horses in the Midwest. ${ }^{14}$ Nightshade toxins are stable and if they are included in forages they remain toxic. They are especially bothersome to the racehorse industry as these toxins can cross-react in the drug screens that are used to test race horses. In most of these cases, identifying contaminating plants in feeds is difficult. Consequently, such false positives usually result in disqualification of those animals..$^{15}$

Henbane is a noxious weed that also grows along fences, roadsides, and waterways. It can invade fields and pastures and can contaminate hay and other prepared forages. The henbane toxins (hypocyamine, hyoscine, and atropine) are similar to those in black nightshade and jimsonweed, so they cause similar diseases. Henbane is generally not palatable unless it is included in prepared forages. 


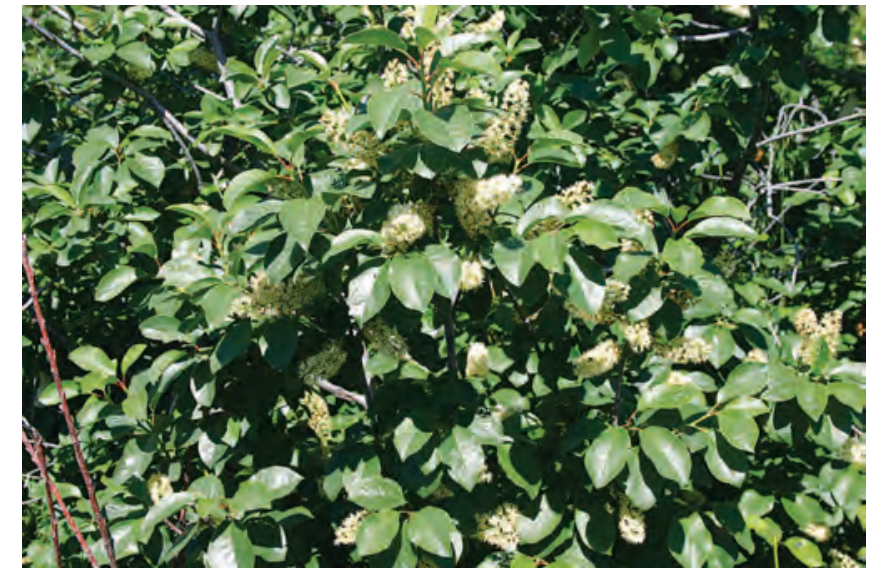

Figure 7. Chokecherry (Prunus virginiana) is a small tree or shrub that grows in thickets and along waterways. It can grow up to $5 \mathrm{~m}$ tall and the leaves are ovate to obovate with serrate margins. The bark is grey with obvious lenticles. The inflorescence is a cylindrical raceme of white fragrant flowers that ripen into dark purple round fruits. The fruit is the only edible portion.

\section{Milkweeds (Asclepias spp.) and Other Cardiac Glycoside-Containing Plants}

Milkweeds (Fig. 6) can be found throughout the world; they grow along roadsides, waterways, and in disturbed areas. Most species contain cardenolides or cardiac glycosides, but the concentrations of these vary between the species and plants. These toxins are similar to digoxin (the toxin in foxglove, Digitalis lanata) that is widely used to treat congestive heart failure. Cardenolides inhibit the sodium-potassium pumps on myocardial membranes resulting in altered conduction and contractility. Similar toxins can also be found in oleander (Nerium oleander), lily of the valley (Convallaria majalis), dogbane or Indian hemp (Apocynum cannabinum), and pheasant's eye (Adonis microcarpa). Milkweeds are most toxic when in the vegetative stage and they remain toxic when included in hay and other forages.

Signs of poisoning are usually sudden death, dyspnea or labored respiration, pulmonary edema, muscular tremors, and a weak rapid pulse. Because no specific treatment is available for large animals, prevention is essential. Milkweeds tend to grow in small patches, so they can be manually removed or treated with various herbicides.

\section{Cyanogenic Glycoside-Containing Plants}

More than 2,000 plants throughout the world have been shown to contain cyanogenic glycosides. Only a handful of these have been associated with poisoning in livestock in the western United States and several of these are often used as chopped green forage and to make hay. Johnsongrass (Sorghum halapense), Sudan grass (Sorghum vulgare), forage sorghums (Sorghum spp.), and arrowgrass (Triglochin spp.; Fig. 7) are generally used as hay. Other cyanogenic plants such as chokecherry (Prunus virginiana; Fig. 8) and serviceberry (Amelanchier alnifolia) often grow along fences and field margins and can inadvertently be included. To become toxic, cyanogenic glycosides must be hydrolyzed to cyanide or prussic acid.

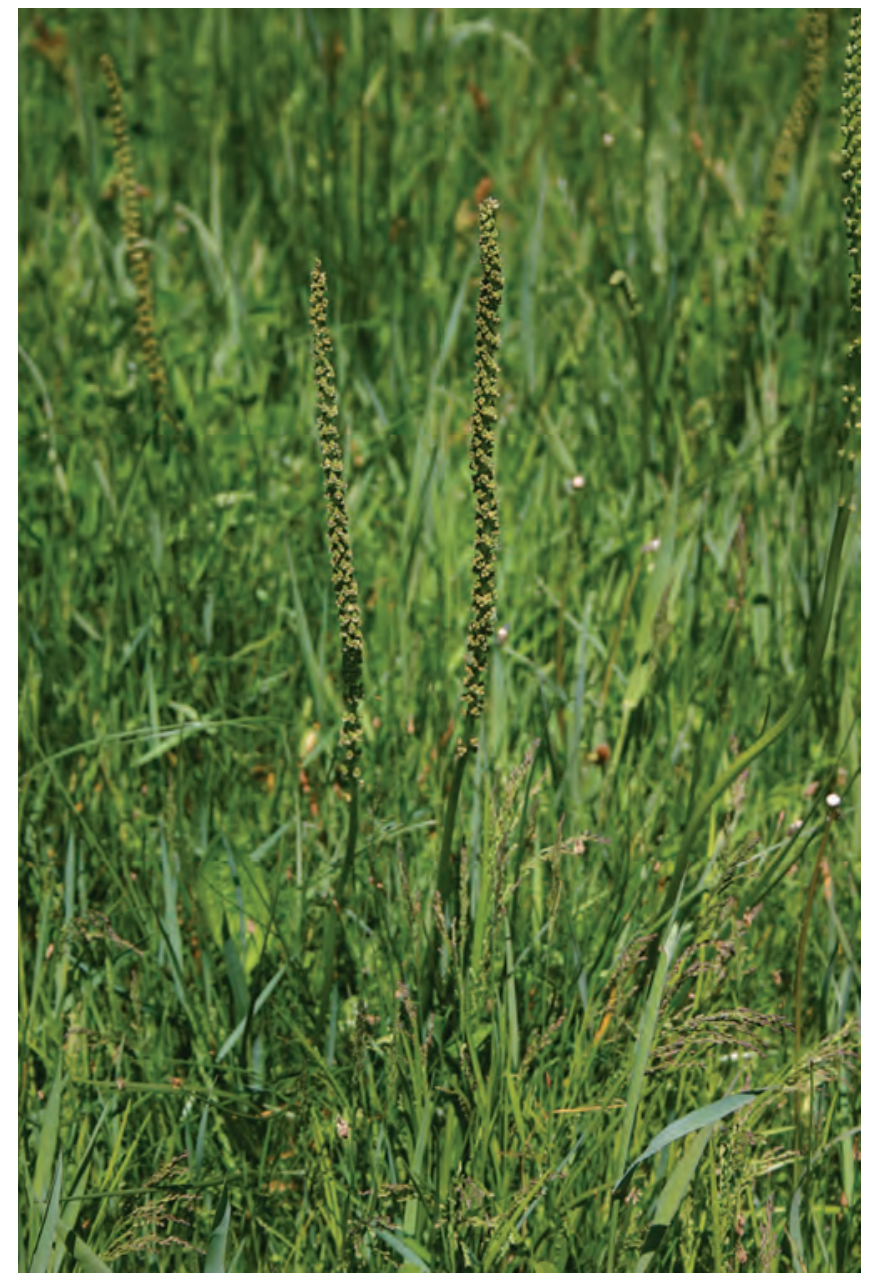

Figure 8. Arrowgrass (Triglochin maritima) is found throughout North America in moist marshlands and pastures. It is a perennial grass-like plant and the leaves are between 15 and $30 \mathrm{~cm}$ long, linear, unjointed, and sheathed at the base. The flower is composed of a that may grow up to $1.5 \mathrm{~m}$ tall. The greenish flowers are inconspicuous and ripen into greenish fruits.

This conversion is facilitated when the plant is damaged as by crushing, chewing, freezing, or wilting. Drying or ensiling the plants decreases the cyanogenic potential because the cyanide is slowly degraded and released over time. The concentration of cyanogenic glycosides in plants varies and can be higher in young plants growing rapidly in cold moist weather, when heavily fertilized, when frost- or drought-stressed, or when the plants are treated with certain herbicides.

Cyanide is highly toxic to all animals because it inhibits cellular respiration. Affected animals cannot use oxygen and develop "cherry red" tissues and blood. Low, nonlethal doses of cyanide have been associated with lathyrism-like disease, goiter, birth defects such as arthrogryposis, spinal cord degeneration, and cystitis. The mechanism of many of these changes is due to damage to nerve coverings called myelin sheaths.

Treatment of cyanide poisoning is difficult because most animals quickly die. Cyanide is quickly dissipated from tissues, so tissues such as liver, muscle, and rumen contents must be collected within a couple of hours of death, frozen 


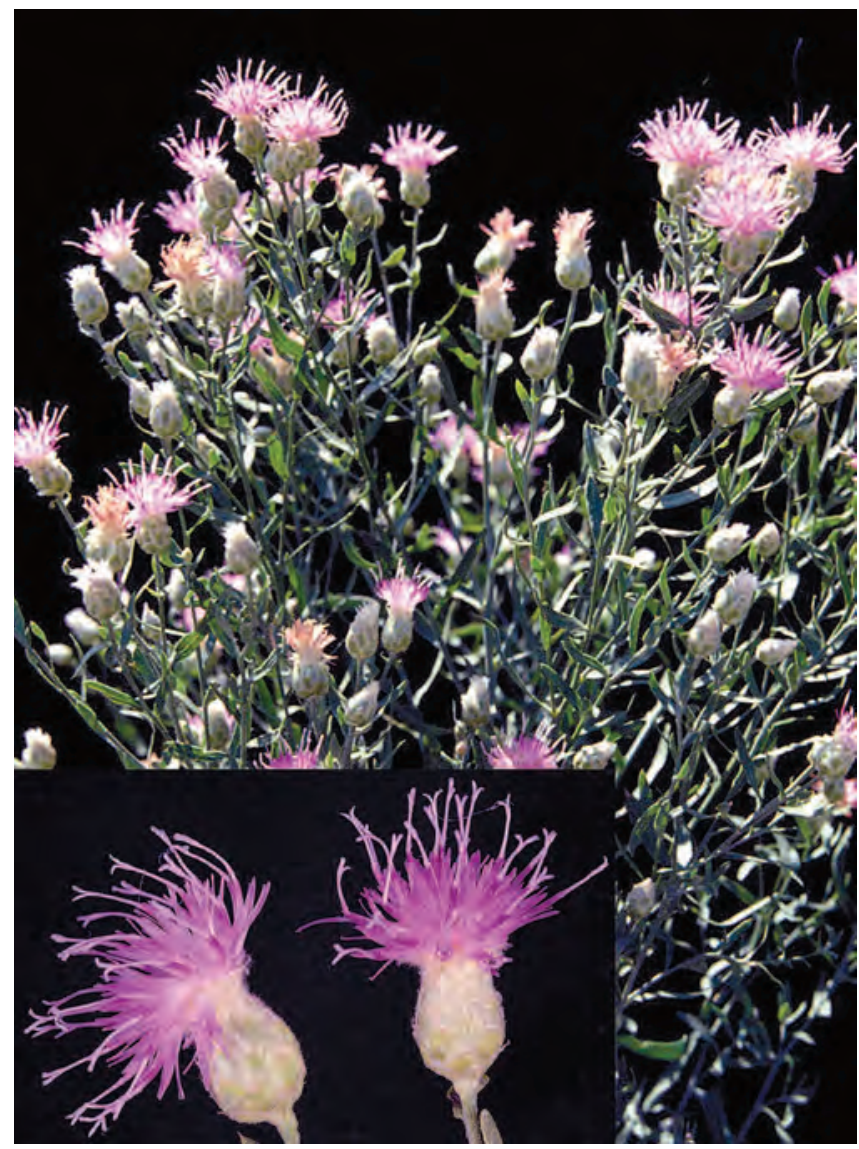

Figure 9. Russian knapweed (Centaurea repens) is a Russian plant that has invaded many parts of the world. It is a perennial erect plant whose branches can grow to about $1 \mathrm{~m}$ tall. The leaves are alternate with toothed margins. The thistle-like flowers are $1-2 \mathrm{~cm}$ in diameter and range from lavender to white. The seeds are white with bristles on one end.

in sealed, airtight containers, and quickly analyzed. If poisoned animals are found, recommended treatments include intravenous sodium nitrite $(22 \mathrm{mg} / \mathrm{kg})$ and sodium thiosulfate $(600 \mathrm{mg} / \mathrm{kg})$. These oxidize hemoglobin, forming methemoglobin. Methemoglobin avidly binds cyanide, protecting the cytochrome oxidase system of cellular respiration from its effects. The best treatment is to avoid harvesting and feeding these plants when they are likely to be toxic. Potentially toxic feeds can be tested for their cyanogenic potential.'

'Picrate test for cyanide: Paper test strips can be prepared by dipping $1 \times 5 \mathrm{~cm}$ strips of paper halfway in picric acid buffer $(0.5 \mathrm{~g}$ picric acid, $5 \mathrm{~g}$ sodium bicarbonate dissolved in $100 \mathrm{~mL}$ distilled water) Let the strips dry and store them in a dark, airtight container. Shred leaves or plant material and fill a $30-\mathrm{mL}$ test tube one-third full of test material. Add 8-10 drops of chloroform and water and insert the test strip into the top of the tube so that it does not touch the test material. Tightly stopper the tube and incubate upright for a couple of hours at $37^{\circ} \mathrm{C}\left(98.6^{\circ} \mathrm{F}\right)$. If the material contains hydrogen cyanide the paper will turn brick red. The rate of color development is proportional to the amount of cyanide present and risk of poisoning. If the strip turns red within 10 minutes, the risk of poisoning is high.

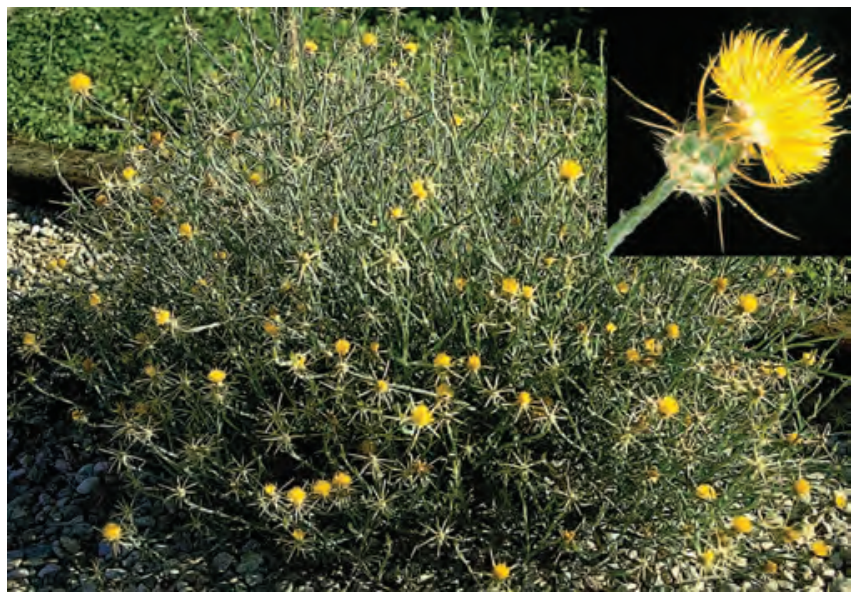

Figure 10. Yellow star thistle (Centaurea solstitialis) is a noxious weed from the Mediterranean that is well established in the western United States. It grows in disturbed areas along fields, roads, and waste areas. It is an annual branching herbaceous weed that grows about $30 \mathrm{~cm}$ tall. The leaves vary from deeply lobed at the base to linear and entire on the stems. The flowers are yellow and the bracts are tipped with stiff yellow spines $(10-20 \mathrm{~mm})$.

\section{Russian Knapweed (Rhaponticum repens) and Yellow Star Thistle (Centaurea solstitialis)}

Russian knapweed (Fig. 9) and yellow star thistle (Fig. 10) produce a unique disease that is specific for horses. These plants are both invasive species that grow in disturbed areas, pastures, and paddocks throughout the western United States. Though several toxins (sesquiterpene lactones) have been identified and proposed, none have been definitively confirmed as the cause of this disease. This is largely due to the extended duration of exposure that is required to produce the disease. All parts of the plants are toxic and they remain toxic when dried and included in hay. Poisoning is seen after horses have eaten the plant for between 30 and 60 days. Affected animals lose the ability to prehend and chew food and to drink water. The lesions are degeneration and necrosis of specific locations in the brain known as the substantia nigra and the globus pallidus, resulting in the morphological description of nigropallidal encephalomalacia. No other disease or toxin has been shown to have such a site-specific effect.

There is no effective treatment for poisoning. Once clinical signs begin, poisoning is nearly always fatal. Affected horses may be treated and maintained with liquids and oral liquid diets, but they do not recover and nearly always continue to deteriorate until they must be euthanized. ${ }^{16}$ The best treatment is management to control the plants to minimize exposure and prevent them from contaminating forages.

\section{Summary}

Many poisonous plants remain toxic and can poison animals when they are included in hay or prepared feeds. Hay fields should be closely inspected and potentially poisonous plants 
should be excluded from harvesting. Other, presumably safe, forages may accumulate saponins, highly soluble carbohydrates, nitrates, or cyanogenic glycosides and this potential should be recognized. Such forage may be tested and treated accordingly to minimize the risk of poisoning.

\section{References}

1. James, L. F., M. H. Ralphs, and D. B. Nielsen. 1988. The ecology and economic impact of poisonous plants on livestock production. Boulder, CO, USA: Westview Press. 428 p.

2. Knight, A. P., and R. G. Walter. 2001. A guide to plant poisoning of animals in North America. Jackson, WY, USA: Teton NewMedia. 376 p.

3. Burrows, G.E., And R. J. Tyrl. 2001. Toxic plants of North America. Ames, IA, USA: Iowa State University Press. 1342 p.

4. Kahn, C., S. Line, and S. Atello. 2011. Bloat (ruminal tympany). In: The Merck veterinary manual. 10th ed. Kendallville, IN, USA: Courier Kendallville Inc. p. 205-209.

5. Lees, G. L. 1992, Condensed tannins in some forage legumes: their role in the prevention of ruminant pasture bloat. Basic Life Sciences 59:915-934.

6. Cheng, K. J., T. A. McAllister, J. D. Popp, A. N. Hristov, Z. Mir, And H. T. Shin. 1998. A review of bloat in feedlot cattle. Journal of Animal Science 76(1):299-308.

7. Hintz, H. F., and L. J. Thompson. 1998. Nitrate toxicosis in horses. Veterinary Clinical Nutrition 5(4):4-5.

8. Burrows, G. E., And R. J. Tyrl. 1989. Plants causing sudden death in livestock. Veterinary Clinics of North America-Food Animal Practice 5(2):263-289.

9. Small, A. C., W. R. Kelly, A. A. Seawright, A. R. Matlocks, and R. Jukes. 1993. Pyrrolizidine alkaloidosis in a two month old foal. Zentralbl Veterinarmed A 40(3):213-218.
10. Huxtable, R. J. 1989. Human health implications of pyrrolizidine alkaloids and herbs containing them. In: P. R. Cheeke [ED.]. Toxicants of plant origin. Boca Raton, FL, USA: CRC Press. p. 41-86.

11. Candrian, U., J. Luthy, P. Schmid, C. Schlatler, and E. Gallasz. 1984. Stability of pyrrolizidine alkaloids in hay and silage. Journal of Agricultural and Food Chemistry 32(4): 935-937.

12. Stegelmeier, B. L., J. A. Edgar, S. M. Colegate, D. R. Gardner, T. K. Sсhock, R. A. Coulumbe, and R. J. Molyneux. 1999. Pyrrolizidine alkaloid plants, metabolism and toxicity. Journal of Natural Toxins 8(1):95-116.

13. Panter, K. E., R. F. Keeler, and D. C. Baker. 1988. Toxicoses in livestock from the hemlocks (Conium and Cicuta spp.). Journal of Animal Science 66(9):2407-2413.

14. Vanderhoff, B. T., and K. H. Mosser. 1992. Jimson weed toxicity: management of anticholinergic plant ingestion. American Family Physician 46(2):526-530.

15. Respondek, F., A. Lallemand, V. Julliand, and Y. Bonnaire. 2006. Urinary excretion of dietary contaminants in horses. Equine Veterinary Journal 36(Suppl):664-667.

16. Selfero, N. A., J. L. Merlassino, and S. Audisio. 1989. Treatment of Centaurea solstitialis poisoning in horses. Therios 13(61):42-44.

Authors are Veterinary Pathologist, USDA-ARS Poisonous Plant Research Laboratory, 1150 East 1400 North, Logan, UT 84341, USA, bryan.stegelmeier@ars.usda.gov (Stegelmeier); and Research Leader, USDA-ARS Poisonous Plant Research Laboratory, 1150 East 1400 North, Logan, UT 84341, USA (Panter). 